\title{
TUG OF WAR BETWEEN SUNNAH TASYRI'IYYAH AND GHAYR TASYRI'IYYAH: A CASE STUDY OF A HADÎTH REGARDING USE OF CAMEL URINE AS MEDICATION
}

\author{
Yusuf Hanafi \\ Universitas Negeri Malang, Indonesia \\ yusuf.hanafi.fs@um.ac.id \\ Article history: \\ Submitted: 02-09-2018 | Revised: 07-11-2018 | Revised: 18-04-2019 | Revised: 10-05-2019 |
}

Accepted: 30-06-2019

\begin{abstract}
Qur'anic texts and Prophetic sunnah are essentially zamâniy and makâniy in nature. According to historical records, Muhammad Shallallâhu 'alaihi wa sallam was playing numerous roles. Therefore, every Moslem really needs to associate sunnah with the status of the Prophet at the time a sunnah was delivered when attempting to understand and practice it. This study aims to discuss the instruction by the Prophet Muhammad, peace and blessings of Allah be upon him, for a group of companions to drink camel urine when they complained of sickness from the perspectives of sunnah tasrî'iyyah and sunnah ghayr tasyrî'iyyah. This study is a literature study using content analysis techniques. The results identified that the hadith above is categorized as sunnah ghayr tasyrî'iyyah. The advice of the Prophet in the hadith above to drink camel urine as a medicine must be understood in the emergency context with no medicine other than camel urine available. This is the opinion of the majority of Moslem scholars that taking medication with something that is najis is not permissible, except in a compelling emergency. Under a normal condition and in the presence of halal medicines, taking medication with something that is najis - like camel urine - is harâm.
\end{abstract}

Keywords: Tug of war, sunnah tasyrî'iyyah, sunnah ghayr tasyrî'iyyah, camel urine.

\begin{abstract}
Abstrak
Teks al-Qur'ân dan sunnah Nabi pada dasarnya bersifat zamâniy dan makâniy. Muhammad SAW berdasarkan catatan sejarah memerankan banyak fungsi. Karenanya, dalam memahami dan mengamalkan sunnah, setiap Muslim sangat perlu mengaitkannya dengan status Nabi saat peristiwa sunnah itu terjadi. Tulisan ini bertujuan untuk mendiskusikan instruksi Nabi Muhammad SAW kepada sekelompok sahabat untuk meminum kencing onta saat mereka mengeluh sakit dari perspektif sunnah tasrî'iyyah dan sunnah ghayr tasyrî'iyyah. Kajian ini merupakan kajian pustaka dengan menggunakan teknik analisis isi. Dari hasil kajian, teridentifikasi bahwa hadis di atas tergolong sunnah ghayr tasyrî'iyyah. Anjuran Nabi untuk meminum air seni onta harus dipahami dalam konteks situasi darurat, dimana tidak ada pilihan obat lain selainnya. Hal ini merupakan pendapat mayoritas ulama bahwa berobat dengan sesuatu yang najis itu tidak diperbolehkan, kecuali dalam kondisi darurat yang memaksa.
\end{abstract}


Kata Kunci: Tarik ulur, sunnah tasyrî'iyyah, sunnah ghayr tasyrî'iyyah, kencing onta.

\section{Introduction}

Muhammad Shallallâhu 'alaihi wa sallam was sent by Allah, may He be praised and exalted, to all mankind ${ }^{1}$ and becomes a blessing for the universe. ${ }^{2}$ This means that the presence of Muhammad Shallallâhu 'alaihi wa sallam brings goodness and blessings for the entire humanity at all time and all places. In light of that, it is clear that the life of Muhammad Shallallâhu 'alaihi wa sallam is confined by the spatial and temporal dimensions. Thus, Prophetic sunnah as one of the primary sources of Islamic teachings aside from the Qur'ân contain teachings that are universal and, at the same time, local and temporal in nature. ${ }^{3}$

In general term, in their understanding of Prophetic sunnah Muslims are classified into two groups. First is those who believe that sunnah are a source of religious teachings regardless of the orthodoxy teaching establishment process. This mode of thought by social scientists are categorized as a textual, ahistorical mode of thought (in that understanding of a sunnah is attempted without concern for the status of the Prophet, as to whether he was acting in his messenger, mufti, judge, leader, or personal capacity). Meanwhile, among the second group

\footnotetext{
'Q.S. al-Saba' (34): 28.

${ }^{2}$ Q.S. al-Anbiyâ' (21): 107.

${ }^{3}$ Sunnah is likened to hadiîh by the majority of Muslim scholars. This refers to all matters attributed to Muhammad Shallallah $u$ 'alaihi wa sallam either sayings ( $q a w l)$, acts $\left(f^{\prime} i l\right)$, stipulation (taqrir) or physical or psychological characteristics, before and after his prophethood. Scholars of Usûl al-Fiqh confine hadith definition to the sayings of the Prophet Muhammad Shallallâhu 'alaihi wa sallam related to law. His law-related acts and taqrîr are then referred to sunnah. M. Quraish Shihab, Membumikan Al-Qur'ân: Fungsi dan Peran Wahyu dalam Kehidupan Masyarakat (Bandung: Mizan, 1996), 56. See also Sayyid Alwi al-Maliki, al-Manhal al-Latîffî Usûl al-Hadîth al-Syarîf (Mecca: Dar al-Rahmah al-Islâmiyyah, t.th.), 2-3.
}

are those who look into and consider critically the circumstance of the occurrence (asbâb alwurûd) of the sunnah. ${ }^{4}$ They understand sunnah contextually by placing Muhammad Shallallâhu 'alaihi wa sallam as a historical being 5 who was constantly faced with a set of options in a pluralistic value system. ${ }^{6}$

A factual case in point regarding the differing types of understanding of the ummah on Prophetic sunnah is the recently heating disagreements and controversies, particularly those taking place via such social media as WhatsApp and the like, surrounding the pros and cons of the use of camel urine as medication, which is based on a Prophetic hadith. ${ }^{7}$ On the basis of the literal (harfiyah) sound, without attention to the historical context, some Muslims have a conviction that camel urine is an efficacious medicine. ${ }^{8}$ Some others are of view that drinking the urine of living things, including camel, poses a considerable risk, as medically, urine is metabolic waste of the

\footnotetext{
${ }^{4}$ M. Quraish Shihab, "Kata Pengantar" dalam Muhammad alGhazali, Studi Kritis atas Sunnah Nabi antara Pemahaman Tekstual dan Kontekstual (Bandung: Mizan, 1996), 8-9. The second understanding model is not very popular as it is hegemonized by Ahl al-Sunnah wa al-Jamâ'ah who tend to understand sunnah literally. Literal understanding is deemed necessary by Ahl al-Sunnah wa al-Jamâ'ah out of the drive to keep and maintain the strength equilibrium of its orthodox teachings. See M. Amin Abdullah, Studi Agama: Normativitas atau Historisitas (Yogyakarta: Pustaka Pelajar, 1996), 315. ${ }^{5}$ Q.S. al-Furqân (25): 20.

${ }^{6}$ Benny Afwadzi, "Hadis di Mata Para Pemikir Modern: Telaah Buku Rethinking Karya Daniel Brown”, Jurnal Studi Ilmu-Ilmu al-Qur'ân dan Hadis 15, no. 2 (2014): 227-242.

${ }^{7}$ Abû 'Abd Allâh Muhammad bin Ismâ‘îl bin Ibrâhim bin alMughîrah bin Bardizbah al-Ju'fiy al-Bukhârîy, Sahîh al-Bukhâriy, Kitab al-Tibb, Bâb al-Dawâ' bi Abwâl al-Ibil, Hadîth Number 5281 (Cairo: Dâr al-Hadîth, 2004), 781.

${ }^{8}$ Lauren Carruth, "Camel Milk, Amoxicillin, and a Prayer: Medical Pluralism and Medical Humanitarian Aid in the Somali Region of Ethiopia", Social Science \& Medicine 120, (November 2014): 405-412. https://doi.org/10.1016/j.socscimed.2014.03.007.
} 
body potentially containing bacteria or poisons, ${ }^{9}$ which unquestionably pose a great danger to the health of the human body. ${ }^{10}$

Mohammed Arkoun holds that Qur'anic verses and Prophetic hadiths that inspire Muslims to behave and act in this world are zamâniy and makâniy (zamkâniy) in nature, that is, involving spatial and temporal dimensions. ${ }^{11}$ This historical awareness, according to Hodgson, offers hope that Islam will be able to better answer future challenges. ${ }^{12}$ This historical approach does not directly translate into total relativization of religious teachings by regarding them as no more than mere products of history. On the other hand, it seeks correct understanding of texts existing in our body of knowledge. ${ }^{13}$ The problem is how to capture the universal, context-independent import of such message if not by referring to the specific cause of the emergence of a teaching or legal product. ${ }^{14}$

As hinted in the Qur'ân, Muhammad Shallallâhu 'alaihi wa sallam was declared not only as a messenger of Allah, but also as an ordinary human. ${ }^{15}$ In history, Muhammad Shallallâhu 'alaihi wa sallam served multiple functions: as a messenger of Allah, as a head

\footnotetext{
${ }^{9}$ Bassem Y. Sheikh, "The Role of Prophetic Medicine in the Management of Diabetes Mellitus: A Review of Literature", Journal of Taibah University Medical Sciences 11, No. 4 (2016): 339-352.

${ }^{10}$ Laila M. Akhu-Zaheya, Esraa M. Alkhasawneh, "Complementary Alternative Medicine Use Among a Sample of Muslim Jordanian Oncology Patients", Complementary Therapies in Clinical Practice 18, no. 2 (2012): 121-126. https://doi.org/10.1016/j. ctcp.2011.10.003.

${ }^{11}$ M. Amin Abdullah, Studi Agama: Normativitas atau Historisitas (Yogyakarta: Pustaka Pelajar, 1996), 64.

${ }^{12}$ Marshal G.S. Hodgson, The Venture of Islam, quoted from Nurcholish Madjid, Kontekstualisasi Doktrin Islam dalam Sejarah (Jakarta: Paramadina, 1994), 35 36.

${ }^{13}$ Ummu Farida, "Diskursus Sunnah Sebagai Sumber Hukum Islam: Perspektif Usûliyyîn dan Muhaddithîn", YUDISIA: Jurnal Pemikiran Hukum dan Hukum Islam 6, no. 1 (2015): 238-255.

${ }^{14}$ Azhar, "Sumber dan Otoritas Hukum dalam Perspektif Islam dan Barat", Jurnal Raudhah 6, no. (2016): 1-11.

${ }^{15}$ Q.S. Ali 'Imrân (3): 144 and al-Kahfî (18): 110.
}

of state, ${ }^{16}$ as a community leader, as a warlord, as a judge, ${ }^{17}$ and as a person. That a sunnah is something emanating from the Prophet Shallallâhu 'alaihi wa sallam indicates that understanding and application of such sunnah should be related to the status of the Prophet Shallallâhu 'alaihi wa sallam when the sunnah event was taking place. The sides inextricably linked to the Prophet's self and the backdrop against which a sunnah emerged assume an important position in the understanding of such sunnah. ${ }^{18}$

Some sunnah are fitter to be understood textually, while some others contextually. Textual understanding and implementation is suitable when certain sunnah, after being related to all sides associated with them, for example, the background of the event, require that they be understood according to what is written in the text. Contextual understanding and implementation of sunnah, on the other hand, is performed if "behind the text" of such sunnah lie a strong hint requiring that such sunnah be understood and implemented not as expressed (textually). ${ }^{19}$

From that point of view, this paper will analyze Prophetic sunnah in relation to diverse functions of Muhammad Shallallâhu 'alaihi wa sallam either as a messenger, as a socio-political leader, or as an ordinary man, with the Prophetic hadith concerning camel urine serving as the subject of this case study. It is of a considerable importance to answer the questions being the central theme of this paper: Are sunnah always presented for tasyrî' purposes? Are sunnah Divine revelation or Prophetic ijtihâd or are they a combination of

\footnotetext{
${ }^{16} \mathrm{~W}$. Montgomery Watt authored a historical book of Muhammad Shallallâhu 'alaihi wa sallam regarding the difference between his function as a Messenger of Allah and as a head of state. See further W. Montgomery Watt, Muhammad: Prophet and Statesman (London: Oxford University Press, 1969).

${ }^{17}$ Philip K. Hitti, History of The Arabs (London: The Macmillan Press Ltd., 1974), 139.

${ }^{18}$ M. Syuhudi Ismail, Sunnah Nabi yang Tekstual dan Kontekstual (Jakarta: Bulan Bintang, 1994), 4 and 6.

${ }^{19}$ Ibid.
} 
both? And what is the implication for the validity of sunnah as a source of tasyrî'?

\section{Sunnah, Divine Revelation or Prophetic Ijtihâd?}

Muslim scholars from usûliyyûn and mutakallimûn realms are of different views regarding the ijtihâd of Muhammad Shallallâhu 'alaihi wa sallam. Some hold that there is no Prophetic ijtihâd in respect of law as he, peace and blessings of Allah be upon him, was directly inspired by Allah, may He be praised and exalted, for that matter. ${ }^{20}$ The logic is that it is forbidden to rely on a source of lower degrees over other sources of higher ones or to use zanniy while ignoring qath 'iy. ${ }^{21}$ This group's argument is based on the verse of Allah, may He be praised and exalted:

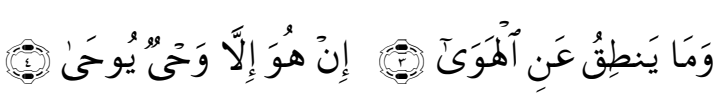

"Nor does he speak from [his own] inclination.

It is not but a revelation revealed." 22

The other group objects this view on the grounds of Qur'anic argumentation, sunnah and common sense. They argue, "The verses on which their argument is based are not appropriate to be used as hujjah as what the verses refer to is the Qur'ân. The meaning of the verses is as narrated by Qatâdah: None of the Qur'ân came from his own inclination but all revealed by Allah, may $\mathrm{He}$ be praised and exalted, to him. ${ }^{" 23}$ Al-Syaukâniy in refuting the first group's argument states that what is referred to in the verses is the Qur'ân. Even if what the first group asserts has the truth, the verses cannot be used as a basis for denying the ijtihâd of the Prophet Shallallâhu 'alaihi wa

\footnotetext{
${ }^{20}$ Muhammad Asriady, "Metode Pemahaman Hadis" Ekspose 16, no. 1 (2017): 314- 323.

${ }^{21}$ Read Muhammad Rawwâs, Qirâ'ah Jadîdah li al-Sirah alNabawiyyah (Beirut: Dâr al-Buhûth al-Ilmiyyah, 2012), 186.

${ }^{22}$ Q.S. al-Najm (53): 3-4.

${ }^{23}$ al-Qurtûbiy, al-Jâmi' lî Ahkâm al-Qur'ân (Cairo: Dâr al-Kutub al-Misriyyah, 1980), 241-242.
}

sallam. ${ }^{24}$

Furthermore, Abû Zahwû underscores that even though the Prophet Muhammad Shallallâhu 'alaihi wa sallam performed ijtihâd by drawing on his intelligence and life experiences under numerous situations, during which heaven revelations did not come down to him, Allah, may He be praised and exalted, did not just "abandon" him. ${ }^{25}$ Allah, may He be praised and exalted, always justified it when the Prophet Shallallâhu 'alaihi wa sallam did right and, on the other hand, reprimanded him if he, peace and blessings of Allah be upon him, did wrong. ${ }^{26}$ Hence, the ijtihâd of the Prophet Shallallâhu 'alaihi wa sallam are basically counted as Divine revelation as well. ${ }^{27}$ Usûl scholars named the laws established through Prophetic ijtihâd al-wahy al-bâtin - they resemble Divine revelation but, in fact, are not Divine revelation. ${ }^{28}$

Al-Qarâfiy is regarded as the first man to sort out the sayings and acts of Muhammad Shallallahhu 'alaihi wa sallam. According to him, Muhammad Shallallâhu 'alaihi wa sallam at times acted as a great imam or qâdiy, but at other times he acted as a deeply knowledgeable mufti. This notion by contextualists is described and developed further, so it is a must to find the context of every sunnah as to whether it was said or acted upon by the sublime man in his position as:

(1) a rasîl, and therefore, it must be true as it originates from Allah, may He be praised and exalted; (2) a mufti, who established a fatwa based on his understanding and the authority given to him by Allah, may He be praised and

\footnotetext{
${ }^{24}$ Yûsuf al-Qaradawiy, al-Sunnah Masdar lî al-Ma'rifah wa alHadârah (Beirut: Dâr Ihyâ' al-Turâts al-'Arabiy, 1996), 86-87. ${ }^{25}$ Q.S. al-Hijr (15):87-99 and Q.S. al-Nahl (16): 125.

26For instance, a case preceding the revelation of Q.S. 'Abasa and the explanation. See Abû Fidâ' Ismâ'îl bin Kathîr, Tafsîr alQur'ân al- 'Azîm, Juz IV (Singapore: Sulaiman Mar'i, t.th.), 470471. See also Muhammad bin 'Alî al-Syawkâniy, Fath al-Qadîr (Beirut: Dâr al-Fikr, 1973), 381-387.

${ }^{27}$ Muhammad Muhammad Abû Zahwu, al-Hadîth wa alMuhaddithûn (Beirut: Dâr al-Kitâb al-'Arabiy, t.t.), 15-16.

${ }^{28}$ al-Qaradâwiy, al-Sunnah Masdar li al-Ma'rifah wa alHadârah, 87.
} 
exalted. This, too, must be true and is generally accepted by every Muslim; (3) a judge, who ruled upon a case. In this event, the ruling, although formally must be correct, might have fallacy materially. This was due to the ability of either of the disputing parties to cover up the truth, while on the other hand, the ruling was only applicable to the disputing parties, ${ }^{29}$ (4) a leader of a community, who adjusted his attitude, guidance, and instruction to the condition and culture of the community he, peace and blessings of Allah be upon him, encountered. In this event, his attitude and guidance must be true and suit the community. Other communities, however, could learn the values contained in such instruction and guidance and apply them according to their respective condition; and (5) a person, because of the privileges bestowed to or imposed onto him by Allah, may He be praised and exalted, in relation to his prophethood (e.g., the obligation to offer night prayer or the permission to gather more than four wives at one time) or because of his uniqueness resulting from his human nature, which differed from that of others (e.g., like or dislike of something). The latter was not the focus of those who are mainly concerned with the sayings and acts of the Prophet Shallallâhu 'alaihi wa sallam that are related to legal matters. ${ }^{30}$

People may be of differing stances regarding the description above. However, it seems that sorting out the sayings and acts of the Prophet Shallallâhu 'alaihi wa sallam is inevitable in that it was also done by his companions. The following are some of the examples.

Buraydah insisted that she be divorced from her husband despite the intercession by the Prophet Shallallâhu 'alaihi wa sallam. This was because she realized that the counsel of the Prophet Shallallâhu 'alaihi wa sallam did not constitute any religious obligation she had to observe. ${ }^{31}$

\footnotetext{
${ }^{29}$ M. Quraish Shihab, "Kata Pengantar" in Muhammad alGhazali, Studi Kritis atas Sunnah Nabi, 9-10.

${ }^{30}$ Ibid., 10.

${ }^{31}$ Ibid.
}

When the Prophet Shallallâhu 'alaihi wa sallam was choosing an army post for his army in the Battle of Badr, al-Habbâb bin al-Mundzir asked whether the location was chosen based on Divine guidance or based on reason and strategy. Upon the answer of the Prophet Shallallâhu 'alaihi wa sallam that it was the result of his reasoning and ijtihâd, alHabbâb proposed another location he deemed more fitting and it was accepted by the Prophet Shallallâhu 'alaihi wa sallam. ${ }^{32}$

It can be seen that from the beginning, the sorting of the sayings and acts of the Prophet Shallallâhu 'alaihi wa sallam was familiar among his companions.

\section{Correlation between the Understanding of Sunnah and the Functions Served by the Prophet}

The main task given to Muhammad Shallallâhu 'alaihi wa sallam, by Allah, may He be praised and exalted, in this world was to be a rasû $^{33}$ to guide mankind in the path of Allah, may He be praised and exalted, and to set a concrete example of how to "promote" Islamic teachings. The Prophetic sunnah, in addition to the Qur'ân, provide directions on what Muhammad Shallallâhu 'alaihi wa sallam has done to "promote" the teachings of Allah, may He be praised and exalted. ${ }^{34}$

Not only did he serve as a messenger of Allah, Muhammad Shallallâhu 'alaihi wa sallam also held the status of an ordinary $\operatorname{man}^{35}$ as a husband, a family member, a friend, a teacher, an educator, a muballigh, a leader, a warlord, a judge, and a head of state. ${ }^{36}$ The predicate $u$ swah hasanah (the best role model) conferred by Allah, may He be praised and exalted, to Muhammad Shallallâhu

\footnotetext{
${ }^{32}$ Ibid.

${ }^{33}$ Q.S. Ali ‘Imrân (3): 144.

${ }^{34} \mathrm{M}$. Syuhudi Ismail, Sunnah Nabi Menurut Pembela, Pengingkar dan Pemalsunya (Jakarta: Gema Insani Press, 1995), 97.

${ }^{35}$ Q.S. al-Kahfi (18): 100

${ }^{36}$ Muhammad Sa'id Ramadhân al-Buthi, Fiqh al-Sirah (Beirut: Dâr al-Fikr, 1980), 18. A book specifically discussing about the self of Muhammad Shallallâhu 'alaihi wa sallam and his various functions, among other 'Abbas Mahmud al-'Aqqad, 'Abqariyyah Muhammad (Cairo: Dâr al-Hilal, 1969).
} 
'alaihi wa sallam, ${ }^{37}$ encompasses all of the functions attributed to him. Mahmud Syaltut said that knowing what the Prophet, peace and blessings of Allah be upon him, did when it was done had immense benefits. ${ }^{38}$ The knowledge on the relationship between the sunnah and the functions of the Prophet Shallallâhu 'alaihi wa sallam is useful for the research of the sunnah status seen from the dalâlah.

On the relationship between the sunnah and the functions of Muhammad Shallallâhu 'alaihi wa sallam, Muslim scholars agreed that such sunnah must be obeyed. ${ }^{39}$ The sunnah teachings that must be obeyed in this case were not confined to the Prophet's elucidation of Qur'ânic verses, but also the Prophet's stipulation not included in the Qur'ân. ${ }^{40}$ Muslim scholars exemplified the Prophetic sunnah related to the Prophet's function as a rasûl with his explanation on the Qur'ân's content, observance of worship, and legal stipulation regarding the lawful and the unlawful (halâl and harâm).

That it is mandatory to obey the guidance contained in the Prophetic sunnah does not mean that all of the dalâlah is qath 'iy in nature. It is not easy to even distinguish between the Prophetic sunnah guidance given in his capacity as a rasul and that in his other functions. Some examples of Prophetic sunnah containing guidance in his function as a head of state and as a leader of community are the deployment of an army and the collection of funds for bayt al-mâl. Some Muslim scholars state that such sunnah do not contain generally applicable sharia provisions. ${ }^{41}$ In this

\footnotetext{
${ }^{37}$ Q.S. al-Ahzâb (33): 21.

${ }^{38}$ Mahmûd Syalțût, al-Islâm 'Aqîdah wa Syarî'ah (Cairo: Dâr al-Qalam, 1966).

${ }^{39} \mathrm{Abd}$ al-Wahhab Khallâf, 'Ilm Usûl al-Fiqh (Jakarta: al-Majlis al-A'la al-Indonesia li al-Da'wah al-Islâmiyyah, 1972). Other grounds on which such opinion is based are as follows: Q.S. alNisâ' (4): 59 dan al-Hashr (59): 7.

${ }^{40}$ According to the majority of Muslim scholars, the Prophetic sunnah not only elucidate and support what is stated in the Qur'ân, but also establish the law not stated in the Qur'ân. See Muhammad 'Ajjâj al-Khatîb, Usûl al-Hadîth 'Ulûmuhu wa Musthalahuhu (Beirut: Dâr al-Fikr, 1975), 46-50.

${ }^{41}$ Abd al-Wahhab Khallaf, 43.
}

case, the Prophetic sunnah present an opportunity and encouragement to the mind to create benefits based on general sharia instructions.

What often constitutes a problem is that there exist some Prophetic sunnah that seem to be related to, on the one side, the function of Muhammad Shallallâhu 'alaihi wa sallam as a "rasûl" and, on the other side, his function as a "head of state" or a "leader of community". For instance, the following hadîth content (matn) reads:

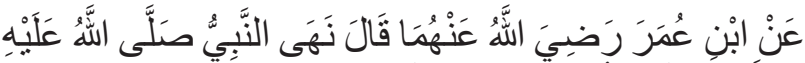

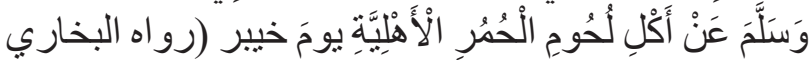

$$
\begin{aligned}
& \text { (ومسلم و غير هما بلفظ البخاري }
\end{aligned}
$$

"Narrated Ibn 'Umar, may Allah be pleased with him: The Prophet Muhammad, peace and blessings of Allah be upon him, forbad (eating) the meat of domesticated himar (donkey) during the Battle of Khaibar". ${ }^{42}$

Some Muslim scholars state that the hadith above is an example showing that Muhammad Shallallâhu 'alaihi wa sallam had the authority to establish a law that is not explicitly stated in the Qur'ân. ${ }^{43}$ Such opinion is well-grounded when seen from the clarity of the hadith content and related to another hadith that reads:

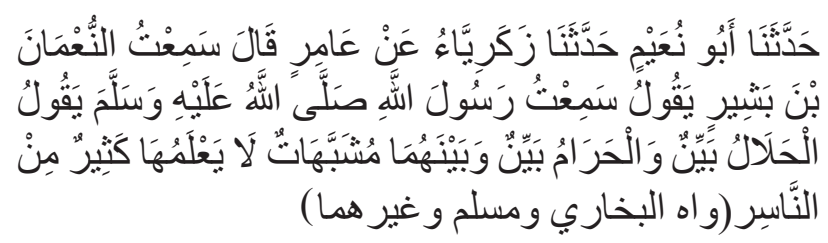

Verily, the lawful is clear and the unlawful is clear, and between the two of them are doubtful

\footnotetext{
${ }^{42} \mathrm{Abu}$ 'Abd Allâh Muhammad bin Ismâ'il al-Bukhâriy, Sahîh Bukhâri, Juz 13 (Beirut: Dâr al-Fikr, t.th.), 118; Abu Husayn Muslim bin al-Hajjâj al-Qushayriy, Sahîh Muslim, Juz 10 (Damascus: Isa Babi al-Halabi, t.t.), 84. This sunnah was also narrated by al-Turmudhi, al-Nasa'i, Ibn Majah, al-Darimi, and Ahmad bin Hanbal. See A.J. Wensinck, al-Mu'jam al-Mufahras li Alfaz al-Hadith al-Nabawy (Leiden: A.J. Brill, 1936), 132.

${ }^{43}$ Muhammad bin 'Ali al-Syaukany, Nayl al-Awtâr min Ahâdith Sayyid al-Akhyâr Syarh Muntaqa al-Akhbâr (Beirut: Dar al-Jîl, 1973).
} 
matters about which many people do not know. ${ }^{44}$

The hadith above explains that the lawfulness and the unlawfulness of matters is clear, but there still exist certain matters that are doubtful. Only a few people are aware of the doubtfulness of such matters. Those who are aware are the mujtahid. ${ }^{45}$ The hadith above indicates that the Prophet, peace and blessings of Allah be upon him, acknowledged matters of zanni status, namely those that belong to the musytabihat category.

When the first hadith is linked to the second one, the impression rendered is that the dalâlah of the first hadîth was qath 'iy al-dalâlah. Is that really the case? Regarding the first hadith, the companions of the Prophet Shallallâhu 'alaihi wa sallam generally adhered to the textual meaning. Ibn 'Abbas, one of the companions of the Prophet Shallallâhu 'alaihi wa sallam who had narrated a lot of hadiths, challenged such general opinion. He argued that the meat of domesticated donkeys is halâl to eat based on the Qur'ânic ground. ${ }^{46} \mathrm{He}$ said that he did not understand the background of the unlawful status of the domesticated donkey meat, as in whether the ban was intended to preserve the domesticated donkey population or whether the application of such ban was specific to the Battle of Khaibar only.

The majority of Muslim scholars beyond the era of the companions of the Prophet Shallallahhu 'alaihi wa sallam also adhere to the textual meaning of the hadith. Various kitâb have discussed the background ( illah) of the unlawful status of domesticated donkey meat as to whether it was intended to preserve the population, whether it was based on the account that the animal is dirty (rijs), whether it was based on the account that the animal is domesticated, or whether it was based on the account that the

\footnotetext{
${ }^{44}$ al-Bukhâriy, Sahîh al-Bukhâriy, Juz I, 90; Muslim, Sahîh Muslim, Juz 7, 290. This sunnah was also narrated by Abu Dâwud, al-Turmudzîy, al-Nasâ'iy, Ibn Mâjah, al-Dârimi, and Ahmad bin Hanbal. See A.J. Wensinck, 258.

${ }^{45}$ Ibn Hajar al-'Asqalaniy, Fath al-Bâri (Beirut: Dâr al-Fikr, t.t.), 127.

${ }^{46}$ Q.S. al-An'âm (6): 145.
}

Prophet, peace and blessings of Allah be upon him, banned it? The reason believed strongly by most Muslim scholars is because the Prophet, peace and blessings of Allah be upon him, banned it. ${ }^{47}$ The Qur'ânic argument referred to by Ibn 'Abbâs was not spared from the discussion. Most Muslim scholars indirectly rejected the use of such argument. To them, the dalâlah of the hadith in question is qath' $i y .^{48}$

Al-Tahâwiy, a scholar of hadith, stated that even if the hadith concerning the unlawfulness of domesticated donkey meat is not mutawâtir, rational consideration can then be used for stipulating the legal status of the animal. ${ }^{49} \mathrm{Al}$ Tahâwiy drew a relation between the asbâb alwurûd of the hadith and the dalâlah, while not all nash of qath'iy al-wurûd status also have a qath'iy al-dalâlah status.

From the description above, it can be confirmed that apparently, the clear textual meaning of a nash (in this case a Prophetic hadith) does not warrant consensus between Muslim scholars in the dalâlah understanding. The problem is, does the difference in the opinions of Muslim scholars in understanding the dalâlah of a given nash justify that the nash in question is zanni? It appears that the validity and strength of each argument underlying the differing opinions should first be assessed before determining the dalâlah status of the nash concerned. ${ }^{50}$

As for the sunnah relating to the function of Muhammad Shallallâhu 'alaihi wa sallam as an ordinary man, Muslim scholars hold that the Prophetic sunnah do not constitute general sharia provisions, unless there is an indication that what was done contained sharia aspects. There are also Prophetic sunnah that exclusively applied

\footnotetext{
${ }^{47}$ Muhammad bin Isma'il al-Shan'ani, Subul al-Salâm Syarh Bulûgh al-Marâm min Jam' Adillah al-Ahkâm (Cairo: Musthafa Bâbiy al-Halabiy, 1960), 73-75.

${ }^{48}$ Syuhudi Ismail, Sunnah Nabi Menurut Pembela, Pengingkar dan Pemalsunya, 101-102.

49al-Syaukâny, Nayl al-Awtâr, 273.

${ }^{50}$ Syuhudi Ismail, Sunnah Nabi Menurut Pembela, Pengingkar dan Pemalsunya, 102.
} 
to Muhammad Shallallâhu 'alaihi wa sallam, for example, the permission to be married to more than four wives (polygamy). What exclusively applied to Muhammad Shallallâhu 'alaihi wa sallam does not constitute generally applied sharia provisions. ${ }^{51}$

The effort to understand Prophetic sunnah by relating them to the function of Muhammad Shallallâhu 'alaihi wa sallam as an ordinary man is evidently still faced with disagreement. An example in case is the Prophetic sunnah of growing beard and mustache. Some Muslim scholars regard this sunnah as a sharia provision, but some others see otherwise. The arising disparity in view has caused a nash to have multiple meanings. If the difference in the points of view can be used as a factor to determine the dalâlah status of a nash, the number of nash with the qath'iy al-dalâlah status will be lowered. ${ }^{52}$

\section{Sorting Out Sunnah Tasyrî’iyyah from Sunnah} Ghair Tasyrî'iyyah

It should be underlined that a sunnah may be considered to contain a tasyrî' element - thereby requiring Muslims to follow and apply the sunnah - or not to contain any tasyrî' and taklîf elements. ${ }^{53}$ It is also important to be clear about the line between sunnah with tasyrî' element that is universal and eternal in character (applicable for all mankind until the Day of Judgment) and those with tasyrî̀ element that is local and temporal (specific to particular conditions or situations). ${ }^{54}$

In this context, Muslims are polarized into two relatively antagonistic cohorts. The first is those who are obsessed with making all sunnah to be in accordance with tasyrî́ purposes, causing it to be compulsory for all people of all ages, places,

\footnotetext{
${ }^{51}$ Ibid., 104.

${ }^{52}$ Ibid.

${ }^{53}$ Muhammad Habibi Siregar, "Legalitas Sunnah Tasyri'iyyah dan Non Tasyri'iyyah: Kritik Motivasi Sahabat dalam Meriwayatkan Hadis", Analytica Islamica 1, no. 2 (2012): 258-280.

${ }^{54}$ Read Kaizal Bay, "Kriteria Sunnah Tasyrî̀iyyah yang Mesti Diikuti”, Jurnal Ushuluddin 23, no. 1 (2015): 78-85. Muhammad Sa'id Ramadhan al-Buthi, Dawâbith al-Maslahah fi Al-Syarî'ah al-Islâmiyyah (Beirut: Muassasah Al-Risâlah, 1977), 23.
}

and conditions to adhere to the sunnah. They overlook the fact that some sunnah emanated from Muhammad Shallallâhu 'alaihi wa sallam in his capacity of an ordinary man, some were driven by tradition, some were influenced by his environment and experience, and some were even accidental beyond his will. Therefore, Usûl scholars maintain that sunnah of this type are no more than arguments of permission (ibâhah) and exhortation (masyrû'ah), unless ritual indications (taqarrub) for Allah, may He be praised and exalted, are found within. ${ }^{55}$

For case in point, in the present time, we can still encounter those who believe that carrying a stick (for a khatîb during Friday shermons) is a sunnah although it is actually not necessary and is not part of the community's tradition. The stick, instead, becomes a burden for the khatîb or gets in his way as he does not use it as a support or for instructing the congregation or for any other purposes. Regrettably, we still can see fanatics reproaching a modern khatîb who mounts a khutbah platform without carrying a stick. ${ }^{56}$

The second, as opposed to the first cohort, is those who intend to set aside sunnah from all worldly practical affairs. Traditions, muamalah, economic and political affairs, management, war, and many other affairs should be completely handed over to humans. Sunnah should not interfere with those affairs by commanding, prohibiting, directing, or demonstrating. Their argument in this case is based on a hadith that is interpreted into a meaning that is irrelevant or incongruent with the context:

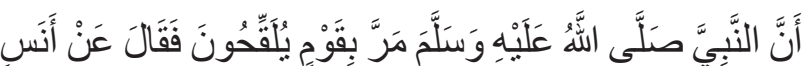

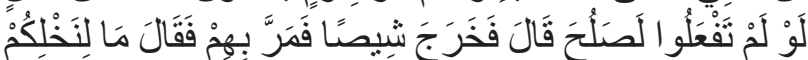

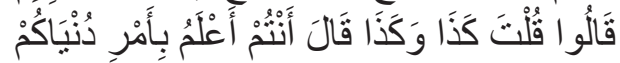

"Narrated Anas, may Allah be pleased with him, the Prophet Shallallâhu 'alaihi

\footnotetext{
${ }^{55}$ Yusuf al-Qaradâwiy, al-Sunnah Masdar li al-Ma'rifah wa alHadârah, 17-18.

${ }^{56}$ Ahmad Bu'ûd, Fiqh al-Wâqi': Usûl wa Dhawâbith (Beirut: Dâr al-Buhûth al-'Asriyyah, 1421 H), 29.
} 
wa sallam passed some people who were fecundating some date palms. He then suggested: Had you not done that, perhaps (the yield) would be better. A few moments later, the Prophet Shallallâhu 'alaihi wa sallam saw them again and asked: How was the yield of your date palms? They told him (that it was unsatisfactory). The Prophet Shallallahhu 'alaihi wa sallam then said: You know better about worldly matters". ${ }^{57}$

This hadith was narrated by Muslim in his Sahîh regarding an account of date palm fecundation and fertilization. ${ }^{58}$

Indeed, matters belonging to worldly, experimental experiences such as agriculture, manufacturing, medicine, among other things, are entirely technical - none of them are included in sunnah tasyrî'iyyah that must be obeyed. For this reason, al-Nawawy placed this sunnah in Sahîh Muslim in the chapter "It is Obligatory to Follow the Prophet's Sayings in Syar'iy Affairs and Optional to Follow the Prophet's Sayings in Worldly Affairs on Account of His Personal View." However, the notion that such hadith as above mentioned lays the basis for setting aside sunnah, even eliminating all religious teachings, from public affairs, and isolating them from social affairs on the grounds that religion is only a mental treatise is rejected by Islam, the Qur'ân, and the sunnah. ${ }^{59}$

If we take a closer look at the attitude of each cohort abovementioned, we can conclude that the first one departs from an immense desire to follow the examples set by the Prophet Shallallâhu 'alaihi wa sallam in his every move that reflects modesty, simplicity, qanâ'ah, and zuhud attitude from the hustle and bustle of the world, away from glamor and wasteful behavior. People of this group are worth praising and rewards for

\footnotetext{
${ }^{57}$ Muslim bin al-Hajjaj al-Qushayri, Sahîh Muslim, Juz XII, 54. ${ }^{58}$ Yusuf al-Qaradâwiy, al-Sunnah Masdar li al-Ma'rifah wa alHadârah, 18.

${ }^{59}$ Ibid., 22.
}

their good intention and enthusiasm to preserve the perfect examples of the Prophet Shallallâhu 'alaihi wa sallam as was done by Ibn 'Umar and other companions. ${ }^{60}$

Nonetheless, it is wrong of them to judge that all these behaviors are part of sunnah and religious doctrines that must be observed and then reprove those who abandon them without considering the settings in which the events were taking place in the time of the Prophet Shallallâhu 'alaihi wa sallam. What they perceived as sunnah were no more than Arabic customs suiting the contexts at that time which the Prophet Shallallâhu 'alaihi wa sallam performed only for preserving the traditions of his people. ${ }^{61}$

Meanwhile, the second group is wrong in mixing up between religious and non-religious affairs. While the religion (read: sunnah) is not concerned with whether we eat on the ground or at a table or whether we eat with hand or with spoon, it reminds us that we should eat and drink with the right hand as opposed to the left. The use of the right hand is not only based on the preference of the Prophet Shallallâhu 'alaihi wa sallam of the right in all things but also based on the grounds that his teaching in this matter is already clear, be it in the form of commandment or prohibition.

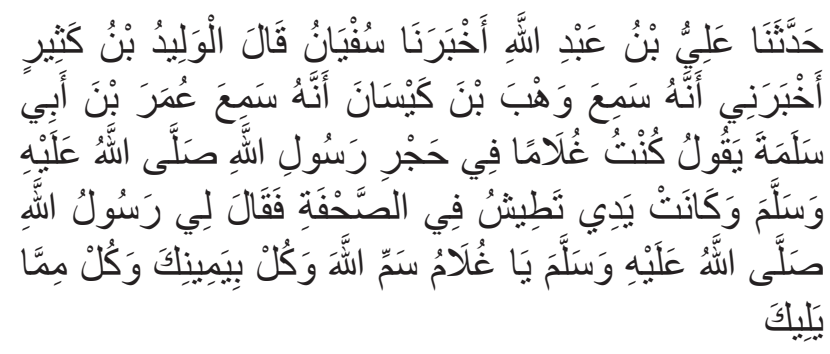

"Narrated Umar bin Salamah: When I was a young boy who lived in the residence of the Messenger of Allah Shallallâhu 'alaihi wa sallam, he advised me when I sneezed: $O$ boy, say the name of Allah, eat with your right

\footnotetext{
${ }^{60}$ Yusuf al-Qaradâwiy, Malâmih al-Mujtama' al-Islâmiy Alladzi Nunsyiduhu (Cairo: Maktabah Wahbah, 2001), 345.

${ }^{61}$ Sa'îd Hawwa, al-Asâs fi al-Sunnah wa Fiqhiha (Cairo: Dâr alSalâm, 1994), 537-538.
} 
hand, and eat what is near to you. ${ }^{62}$

He Shallallâhu 'alaihi wa sallam also said:

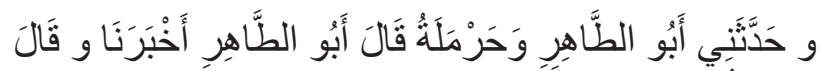

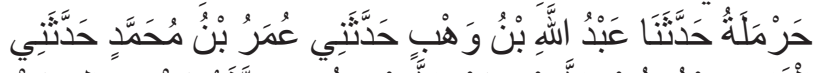

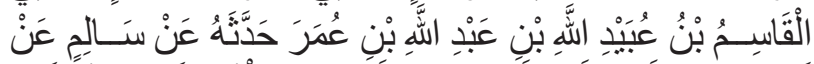

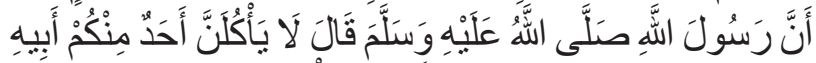

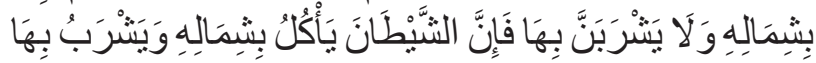

"Do not eat and drink with the left hand, for the shaytan eats with his left hand." 63

The right way to respond to the two antagonistic groups above mentioned is to be poised and take the middle position. It is suggested to draw a line between sunnah containing tasyrî' that must be followed and those that do not contain tasyrî (also frequently termed sunnah irsyâdiyyah) as well as between tasyrî́ that is universal and eternal in character and one that is specific. This will require caution and deep understanding of the book of Allah, may He be praised and exalted, and the sunnah of His Messenger Shallallâhu 'alaihi wa sallam.

\section{Consequences of Sunnah Tasyrî'iyyah and Sunnah Ghair Tasyrî'iyyah in Life Practices}

After sorting out between sunnah tasyrî'iyyah and sunnah ghayr tasyrî'iyyah, the next concern is on what basis, and how, the sorting is performed. This discussion will subsequently be more concerned with Usûl al-Fiqh than Usûl al-Hadith although both are interlinked. Among the most intensive in elucidating this matter in modern times is Syaikh Mahmûd Syalțût. He largely refers to the writings by Syah Wali Allâh al-Dahlawiy, Syihâb al-Dîn al-Qarâfy al-Misriy, Rasyîd Ridhâ, and more. ${ }^{64}$

According to Syaltût, everything emanating from Muhammad Shallallâhu 'alaihi wa sallam

\footnotetext{
62al-Bukhâriy, Sahîh al-Bukhâry, Juz 16, 470.

${ }^{63}$ Muslim bin al-Hajjâj al-Qushayriy, Sahîh Muslim, Juz 10, 297.

${ }^{64} \mathrm{Ibrâhim} \mathrm{al-Hasnayâni,} \mathrm{al-Ta'sîl} \mathrm{al-Syar'îy} \mathrm{li} \mathrm{Fiqh} \mathrm{al-Wâqi'}$ (Cairo: Dâr al-Fikr, 2009), 61.
}

that are codified in sunnah books, in the form of either statements, acts, or taqrîr, can be classified into several categories. Among the first are those that have the nature of human needs, such as eating, drinking, sleeping, walking, making visits, reconciling two conflicting people in traditional manners, helping out, and bargaining in trades. The second is those that are experimental and related to personal and social habits in nature, such as sunnah on agriculture, medicine, and the length of clothing. The third is those related to personal prowess as a manifestation of interaction with particular conditions, such as division of an army into battlefields, hiding, returning, running, or other things under certain conditions. ${ }^{65}$ The three things aforementioned do not belong to syara' that must be either performed or deserted. The acts of Muhammad Shallallâhu 'alaihi wa sallam above neither constitute tasyri' nor source of tasyrî'. ${ }^{66}$

The fourth category covers those of tasyri purpose, which are divided into three: (1) the sunnah delivered by Muhammad Shallallâhu 'alaihi wa sallam in the form of tabligh in his capacity of a rasul, as in his explanation of verses that are mujmal (having global meanings), with him performing takhsîs on verses that are general in nature and taqyîd on verses that are absolute in nature, or his explanation on worship practices ordained in the Qur'ân, lawfulness and unlawfulness, and matters of aqîdah, akhlâq, and others related to the aforementioned. Sunnah such as these are delivered for general tasyrî' purpose and are applicable until the Final Day. If they are prohibitive, everybody is obliged to abandon what are prohibited, and there is no other way than knowing and obeying them.

(2) The sunnah delivered by Muhammad Shallallâhu 'alaihi wa sallam in his capacity as an

\footnotetext{
${ }^{65}$ Read Muhammad Ahmad Burkab, al-Masâlih al-Mursalah wa Atsaruhâ fi Murûnah al-Fiqh al-Islâmi (Beirut: Dâr al-Fikr, 2001), 98.

${ }^{66}$ Yusuf al-Qaradâwiy, al-Sunnah Masdar li al-Ma'rifah wa alHadârah, 49-50.
} 
imâm and leader of Muslims, such as deploying an army, using and distributing the treasure in bayt al-mâl for the entitled, collecting the treasure from lawful sources, appointing qâdhi and wali, dividing spoils of war (ghanimah), establishing agreements, and other things that are imâmah and intended for public interest. Sunnah such as these are not for general tasyrî' purposes, so not anyone is permitted to follow them without the permission of the Imâm, and in no way is one allowed to do something as he wills on the account that the Prophet Shallallâhu 'alaihi wa sallam, himself performed or commanded it.

(3) The sunnah performed by Muhammad Shallallâhu 'alaihi wa sallam as trial (qadhâ') measures. Besides serving the functions as a rasîl who delivered the law of Allah, may He be praised and exalted, and as a leader of Muslims who governed and took care of every sociopolitical affairs of theirs, he also served the function of a judge who delivered rulings on various cases with evidence, oaths, or threats. As with the previous type of sunnah, these sunnah are not for general tasyrî̀' purpose, so it is not permissible for one to conduct something on the grounds that it is the stipulation of the Prophet Shallallâhu 'alaihi wa sallam, who imposed upon it an undisputable law. However, in this case, he is bound to the decision of the judge on it, while the Prophet Shallallâhu 'alaihi wa sallam acted as one whose measures had the nuance of adjudication. ${ }^{67}$

Thus, it is critical to know where the behavior of Muhammad Shallallâhu 'alaihi wa sallam was headed because what often happens is uncertainty of where the sunnah's meaning is leaning to. Oftentimes, Muhammad Shallallâhu 'alaihi wa sallam is not seen in his capacities other than as a rasîl in performing, saying, or establishing something. In light of that, we can find that most sunnah are interpreted as syara' and mandûb although there is a possibility that something was delivered for purposes other than tasyrî̀.

\footnotetext{
${ }^{67}$ Ibid., 50-51
}

Many sunnah only constitute human character, behavior, actions, and experience. Besides, many sunnah that have the imâmah or qadhâ' nuance are interpreted to have general tasyrî' purpose. From this misunderstanding come legal disorder and overlapping of meanings.

An example of this is as follows. It is true that the Prophet Shallallâhu 'alaihi wa sallam said:

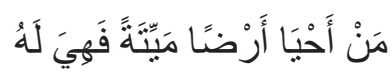

"Whoever cultivates a dead land, it becomes his." ${ }^{68}$ To this sunnah, Muslim scholars respond in different ways as to whether it was delivered as a general tablikh or fatwa, so it becomes a general law, that is, everyone is entitled to cultivate an empty land and then own it, either with the permission of the imâm or not, or whether it was delivered in the capacity of Muhammad Shallallâhu 'alaihi wa sallam as an imâm or leader, causing it not to be a general tasyrî' and, thus, no one has the right to cultivate an empty land without the permission of the imâm. ${ }^{69}$

For another example, the Prophet Shallallâhu 'alaihi wa sallam spoke to Hindun binti 'Utbah when she was bringing a charge about her husband, Abu Sufyan, to him Shallallâhu 'alaihi wa sallam as narrated below.

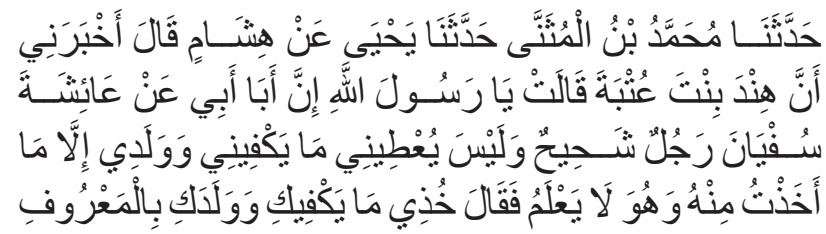

"Abû Sufyân is a miser. He does not give what is sufficient to me and my children," complained Hindun. Then, the Prophet Shallallâhu 'alaihi wa sallam said, "Take what is sufficient for you and your children, and the amount should be just and reasonable." ${ }^{70}$ Muslim scholars are in disagreement regarding the dalâlah of this

\footnotetext{
68al-Bukhâriy, Sahîh al-Bukhâriy, Juz VIII, 144.

${ }^{69}$ This matter is also explained in the Kitab Ihyâ' al-Mawât. The first school of thought adhered by the majority of fuqahâ', while Abu Hanifah subscribed to the second school of thought. See alQaradâwiy, al-Sunnah Masdar li al-Ma'rifah wa al-Hadârah, 51. ${ }^{70}$ al-Bukhariy, Sahîh al-Bukhâriy, Juz XVI, 448.
} 
sunnah as to whether it was delivered as a general tabligh or fatwa, so that one who feels that he or she does not receive what he or she is entitled to may take from someone else who keeps his or her entitlement without the knowledge of this someone or whether it was delivered as a judicial case, so one may not take his or her entitlement or the like - due to the difficulty taking - except through a judicial process. ${ }^{71}$

\section{Camel Urine as a Medicine: A Case Study of Sunnah Ghair Tasyrî'iyyah}

A factual case in point regarding the differing types of understanding of the ummah on Prophetic sunnah, as to whether they are for tasyrî' purpose or not, is the recently heating disagreements and controversies, ${ }^{72}$ particularly those taking place via such social media as WhatsApp and the like, surrounding the pros and cons of the use of camel urine as a medicine, which is based on the following Prophetic hadith:

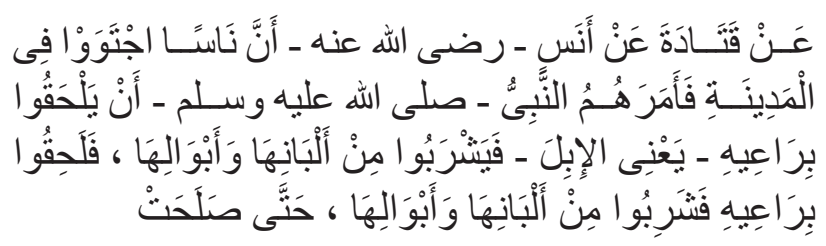

"Narrated Qatadah from the companion Anas, may Allah be pleased with him, that some people in Medina were complaining about their sickness. Hearing their complaint, the Prophet Muhammad Shallallâhu 'alaihi wa sallam then directed them to a camel shepherd to drink the milk and urine of the camels. They

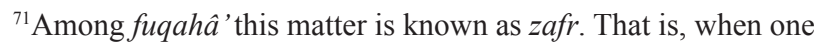
is entitled to others and he or she has the capability to take his or her belongings of the same type or value as the belongings of those people, is he or she allowed to take those belongings? On this matter Muslim scholars are of different opinions. Some scholars allow it regardless of whether the items taken are his or her right of the same type not, without the knowledge of those other people or not, under the condition that this taking should not cause fitnah and malignance. Some others, on the other hand, are against it. Some scholars provide a detailed explanation of this matter. al-Qaradâwiy, al-Sunnah Masdar lî al-Ma'rifah wa al-Hadârah, 52-53.

${ }^{72}$ Read Johar Arifin, "Pendekatan Ulama Hadis dan Ulama Fiqh dalam Menelaah Kontroversial Hadis", Jurnal Ushuluddin XXII, no. 2 (2014): 148.
}

followed his command and, as a result, they regained their health". ${ }^{73}$

On the basis of the literal (harfiyyah) sound, without attention to the historical context, some Muslims have a conviction that camel urine is an efficacious medicine. ${ }^{74}$ Some others are of view that drinking the urine of living things, including camel, poses a considerable risk, as medically, urine is metabolic waste of the body potentially containing bacteria or poisons, which unquestionably pose a great danger to the health of the human body. ${ }^{75}$

Moreover, most Muslim scholars declare the urine of living things, including camel, as najis, although a different view of some mujtahid, like Mâlik and Imâm Ahmad, regarding the purity of the urine of animals whose flesh is allowed to eat exists. In the book al-Fiqh al-Islâmi wa Adillatuhu, Wahbah al-Zuhaili states:

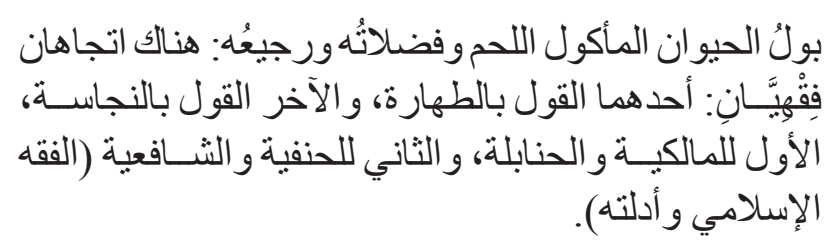

"With regard to animals whose flesh, as well as other metabolic waste, is lawful to consume, Muslim scholars are split into two in their legal view. The first one declares its purity, while the second does its impurity. The first one is the legal view of Mâliki and Hanbali, while the second is of Hanafi and Syâfi' $i{ }^{76}$

This is supported by Ibnu Hajar in Fathul Bari:

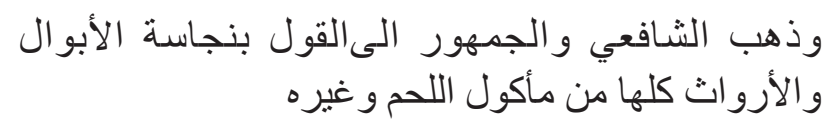

\footnotetext{
${ }^{73}$ al-Bukhariy, Sahîh al-Bukhâriy, 781.

${ }^{74}$ Sulastri Chaniago, "Fikih dan Kesehatan: Tinjauan terhadap Hukum Terapi Urin", JURIS 10, no. 2 (2011): 162-169.

${ }^{75}$ Fitri Yeni M. Dalil, "Hadis-Hadis tentang Farmasi: Sebuah Kajian Integratif dalam Memahami Hadis Rasulullah", Batusangkar International Proceeding, 15-16 Oktober 2016, 309-326.

${ }^{76}$ Wahbah al-Zuhailiy, al-Fiqh al-Islâmiy wa Adillatuhu (Beirut: Dâr al-Fikr, 1428), 333.
} 
"Imam Syâf'i and the majority of Muslim scholars are of view that the urine and excrement of animals, either ones whose flesh is lawful to consume or ones whose flesh is not, is najis". ${ }^{77}$

The next question is how we should understand the Prophetic hadith instructing the use of camel urine as medicine above. To answer this question, we may identify the right attitude by analyzing the fatwa of a mufti from al-Azhar, Egypt, Athiyyah Syaqr, in the book Fatâwa al-Azhar, in which he states:

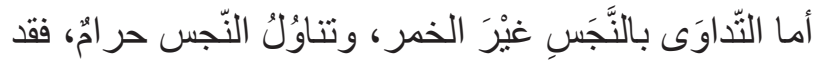

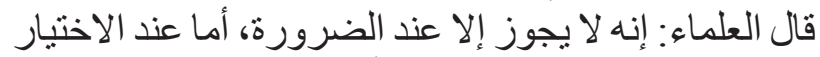

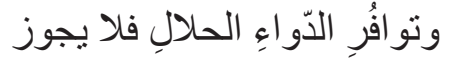

"Using something that is najis, other than khamr, as a medicine, including consuming it, is haram. The ulema hold that taking medication with something that is najis is not permissible except in a compelling emergency. Under a normal condition and in the presence of halal medicines, taking medication with something that is najis is haram". ${ }^{78}$

The opinion of the mufti above is clearly consistent with the commandment of Allah, may He be praised and exalted, in surah alBaqarah verse 173, stating that Allah, may He be praised and exalted, set the boundaries of what is prohibited we must never transgress except in emergencies.

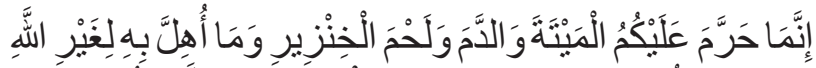

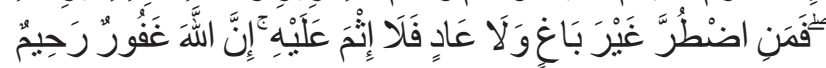

"He has only forbidden to you dead animals, blood, the flesh of swine, and that which has been dedicated to other than Allah. But whoever is forced [by necessity], neither desiring [it] nor transgressing [its limit],

${ }^{77}$ Ibn Hajar, Fath al-Bâri (Cairo: Dâr al-Kutub al-Arabiyyah, 1431), 562.

${ }^{78}$ Athiyyah Syaqr, Fatâwa al-Azhar (Cairo: Dâr al-Buhûth alIlmiyyah, 1430), 444. there is no sin upon him. Indeed, Allah is Forgiving and Merciful". ${ }^{79}$

Based on the description and explanation above, it can be concluded that the advice of the Prophet Shallallâhu 'alaihi wa sallam in the hadith above to drink camel urine as a medicine must be understood in the right context, namely in an emergency with no medicine other than camel urine available. ${ }^{80}$

Back to the main theme of this writing, there is a possibility that certain Prophetic sunnah/ hadiths are better understood based on the textual (explicit) dictum. But at times, some others are better understood contextually (while capturing their implicit message). Textual understanding and implementation of a sunnah is preferred if it, after being related to the sides relevant to it (e.g., the background of event), still requires understanding according to what is written in the text of the sunnah. On the other hand, contextual sunnah understanding and implementation is preferred if "behind" the text of the sunnah lies a strong indication requiring that such sunnah be understood and implemented not as written. ${ }^{81}$

Thus, it can be reconfirmed that Prophetic sunnah can be broken down into two, namely sunnah tasyrî'iyyah (ones containing sharia, so it is mandatory to observe such sunnah as he Shallallâhu 'alaihi wa sallam, delivered them in his capacity as a rasul and as a mufti who was guided by Divine revelation) and sunnah ghayr tasyrî'iyyah (ones delivered by the Prophet Shallallâhu 'alaihi wa sallam not for the promulgation of religious law as they were based on his human reasoning and ijtihâd). It is beyond question that the sunnah of the latter type should not be understood in a harfiyah and textual

\footnotetext{
${ }^{79}$ Q.S. al-Baqarah: 173.

${ }^{80}$ Rahmawati, "Studi Pendekatan Hadis-Hadis tentang Berobat dengan Benda-Benda Najis atau Haram", Al-Hurriyah 16, no. 2 (2015): 93-104.

${ }^{81}$ Zainul Arifin, "Asbab Wurud al-Hadits dalam Memahami Hadis Ahkam", de Jure: Jurnal Syariah dan Hukum 3, no. 2 (2011): 184-196.
} 
manner. ${ }^{82}$ Contrarily, they should be understood contextually lest ahistorical understanding that is inconsistent with the dynamics of world development happens as is the case of the use of camel urine as a medicine. ${ }^{83}$

\section{Conclusions}

Most sunnah - sayings, acts, or taqrîr - are delivered for tasyrî purposes and obliges following. Some sunnah were not delivered for tasyrî̀ purposes and no obligation to follow these sunnah. In order to properly sort out the sunnah, a good understanding of the status played by the Prophet Muhammad was needed when the sunnah occurred (as rasûl, mufti, judge, community leader and person).

The results identified that the advice of the Prophet to drink camel urine as a medicine is categorized as sunnah ghayr tasyrî'iyyah. The hadith must be understood in the emergency context with no medicine other than camel urine available. This conclusion is supported by the opinion of the majority of Moslem scholars that taking medication with something that is najis is not permissible, except in a compelling emergency. Under a normal condition and in the presence of halal medicines, taking medication with something that is najis - like camel urine - is harâm.

\section{References}

Abdullah, M. Amin. Studi Agama: Normativitas atau Historisitas. Yogyakarta: Pustaka Pelajar, 1996.

Abû Zahwu, Muhammad Muhammad. al-Hadîth wa al-Muhaddithûn. Beirut: Dâr al-Kitab al-'Arabiy, t.th.

\footnotetext{
${ }^{82}$ Rakhmawati Zulkifli, "Moderasi Pemahaman Hadis dan Hukum Islam Menurut Al-Qaradhawiy", el-Buhuth 1, no. 1 (2018): 41-55.

${ }^{83}$ Osama A. Alkhamees, Saud M. Alsanad, "A Review of the Therapeutic Characteristics of Camel Urine", African Journal of Traditional, Complementary and Alternative Medicines 14, no. 6 (2017): 120-126.
}

Afwadzi, Benny. "Hadis di Mata Para Pemikir Modern: Telaah Buku Rethinking Karya Daniel Brown". Jurnal Studi Ilmu-Ilmu al-Qur'ân dan Hadis 15, no. 2 (2014).

Alkhamees, Osama A., Saud M. Alsanad, "A Review of the Therapeutic Characteristics of Camel Urine". African Journal of Traditional, Complementary and Alternative Medicines 14, no. 6 (2017).

al-'Aqqâd, 'Abbâs Mahmûd. 'Abqariyyah Muhammad. Kairo: Dar al-Hilâl, 1969.

Arifin, Johar. "Pendekatan Ulama Hadis dan Ulama Fiqh dalam Menelaah Kontroversial Hadis". Jurnal Ushuluddin XXII, no. 2 (2014).

Arifin, Zainul. "Asbab Wurud al-Hadits dalam Memahami Hadis Ahkam”. de Jure: Jurnal Syariah dan Hukum 3, no. 2 (2011).

al-'Asqallâniy, Ibn Hajar. Fath al-Bâri. Beirut: Dâr al-Fikr, t.th.

Asriady, Muhammad. "Metode Pemahaman Hadis". Ekspose 16, no. 1 (2017).

Azhar. "Sumber dan Otoritas Hukum dalam Perspektif Islam dan Barat". Jurnal Raudhah 6, no. 2 (2016).

Bassem Y. Sheikh. "The Role of Prophetic Medicine in the Management of Diabetes Mellitus: A Review of Literature", Journal of Taibah University Medical Sciences 11, no. 4 (2016).

Bay, Kaizal. "Kriteria Sunnah Tasyri'iyyah yang Mesti Diikuti”. Jurnal Ushuluddin 23, no. 1 (2015).

al-Bukhâriy, Abû 'Abd Allâh Muhammad bin Ismâ'il. Sahîh al-Bukhâriy. Beirut: Dâr al-Fikr, t.th.

Burkab, Muhammad Ahmad. al-Mashâlih alMursalah wa Atsaruha fi Murûnah al-Fiqh al-Islâmi. Beirut: Dâr al-Fikr, 2001. 
al-Buthiy, Muhammad Sa'id Ramadhân. Dawâbith al-Maslahah fî al-Syarî'ah al-Islâmiyyah. Beirut: Muassasah AlRisâlah, 1977.

-------. Fiqh al-Sîrah. Beirut: Dâr al-Fikr, 1980.

Bu'ûd, Ahmad. Fiqh al-Wâqi': Usûl wa Dawâbith. Beirut: Dâr al-Buhûts al-'Ashriyyah, 1421 H.

Carruth, Lauren. "Camel Milk, Amoxicillin, and a Prayer: Medical Pluralism and Medical Humanitarian Aid in the Somali Region of Ethiopia". Social Science \& Medicine 120 (November 2014), https://doi. org/10.1016/j.socscimed.2014.03.007..

Chaniago, Sulastri. 2011. "Fikih dan Kesehatan: Tinjauan terhadap Hukum Terapi Urin". JURIS 10, no. 2 (2011).

Dalil, Fitri Yeni M. "Hadis-Hadis tentang Farmasi: Sebuah Kajian Integratif dalam Memahami Hadis Rasulullah". Batusangkar International Proceeding, 15-16 Oktober 2016.

Farida, Ummu. "Diskursus Sunnah Sebagai Sumber Hukum Islam: Perspektif Usûliyyîn dan Muhaddithîn". YUDISIA: Jurnal Pemikiran Hukum dan Hukum Islam 6, no. 1 (2015).

al-Hasnayani, Ibrâhim. al-Ta 'sîl al-Syar'iy li Fiqh al-Wâqi'. Kairo: Dâr al-Fikr, 2009.

Hawwa, Sa’îd. al-Asâs fi al-Sunnah wa Fiqhiha. Kairo: Dâr al-Salâm, 1994.

Hitti, Philip K. History of The Arabs. London: The Macmillan Press Ltd., 1974.

Hodgson, Marshal G.S. The Venture of Islam. London: Cambridge University, 1978.

Ibn Kathîr, Abû al-Fida' Ismâ'il. Tafsîr al-Qur'ân al-'Azîm. Singapura: Sulaiman Mar'i, t.th.

Ibn Hajar. Fath al-Bâri. Kairo: Dâr al-Kutub alArabiyyah, 1431.
Ismail, M. Syuhudi. Sunnah Nabi yang Tekstual dan Kontekstual. Jakarta: Bulan Bintang, 1994.

-----. Sunnah Nabi Menurut Pembela, Pengingkar dan Pemalsunya. Jakarta: Gema Insani Press, 1995.

Khallâf, Abd al-Wahhâb. 'Ilm Usûl al-Fiqh. Jakarta: al-Majlis al-A'la al-Indunisia li al-Da’wah al-Islâmiyyah, 1972.

al-Khatîb, Muhammad 'Ajjâj. Usûl al-Hadîth 'Ulumuhu wa Mustalahuhû. Beirut: Dâr al-Fikr, 1975.

Madjid, Nurcholish. Kontekstualisasi Doktrin Islam dalam Sejarah. Jakarta: Paramadina, 1994.

al-Maliki, Sayyid Alwi t.t. al-Manhal al-Latîf fi Usûl al-Hadîth al-Syarîf. Makkah: Dâr al-Rahmah al-Islâmiyyah.

al-Qaradâwiy, Yûsuf. al-Sunnah Masdar li alMa'rifah wa al-Hadârah. Beirut: Dâr Ihyâ' al-Turâth al-'Arabiy, 1996.

-------. Malâmih al-Mujtama' al-Islâmiy alladzi Nunsyiduhu. Kairo: Maktabah Wahbah, 2001.

al-Qurțûbiy. al-Jâmi' li Ahkâm al-Qur'ân. Kairo: Dâr al-Kutub al-Misriyyah, 1980.

al-Qushairy, Abû Husayn Muslim bin al-Hajjâj. Sahîh Muslim. Damaskus: Isa Bâbiy alHalabiy, t.th.

Rahmawati. 2015. "Studi Pendekatan HadisHadis tentang Berobat dengan BendaBenda Najis atau Haram". Al-Hurriyah 16, no. 2 (2015).

Rawas, Muhammad. Qirâ'ah Jadîdah li al-Sîrah al-Nabawiyyah. Beirut: Dâr al-Buhûth alIlmiyyah, 2012.

al-Shan'âniy, Muhammad bin Isma'il. Subul alSalâm Syarh Bulûgh al-Marâm min Jam' Adillah al-Ahkâm. Kairo: Mustafa Bâbiy al-Halabiy, 1960. 
al-Shawkâniy, Muhammad bin 'Ali. Fath alQadîr. Beirut: Dâr al-Fikr, 1973.

-------. Nayl al-Awtâr min Ahâdith Sayyid alAkhyâr Syarh Muntaqa al-Akhbâr. Beirut: Dâr al-Jil, 1973.

Shihab, M. Quraish. "Kata Pengantar" dalam al-Ghazali, Muhammad. Studi Kritis atas Sunnah Nabi antara Pemahaman Tekstual dan Kontekstual. Bandung: Mizan, 1996.

------. Membumikan Al-Qur'ân: Fungsi dan Peran Wahyu dalam Kehidupan Masyarakat. Bandung: Mizan, 1996.

Siregar, Muhammad Habibi. "Legalitas Sunnah Tasyri'iyyah dan Non Tasyri'iyyah: Kritik Motivasi Sahabat dalam Meriwayatkan Hadis”. Analytica Islamica 1, no. 2 (2012).

Syalțût, Mahmûd. al-Islâm 'Aqîldah wa Syarî'ah. Kairo: Dâr al-Qalam, 1966.
Syaqr, Athiyyah. Fatâwa al-Azhar. Kairo: Dâr al-Buhûts al-Ilmiyyah, 1430.

Watt, W. Montgomery. Muhammad: Prophet and Statesman. London: Oxford University Press, 1969.

Wensinck, A.J. al-Mu'jam al-Mufahras li Alfâdh al-Hadith al-Nabawiy. Leiden: A.J. Brill, 1936.

Zaheya, Laila M. Akhu., Alkhasawneh, Esraa M., "Complementary Alternative Medicine Use Among a Sample of Muslim Jordanian Oncology Patients". Complementary Therapies in Clinical Practice 18, no. 2 (2012). https://doi.org/10.1016/j.ctcp. 2011.10.003.

al-Zuhaili, Wahbah. al-Fiqh al-Islâmi wa Adillatuhu. Beirût: Dâr al-Fikr, 1428.

Zulkifli, Rakhmawati. "Moderasi Pemahaman Hadis dan Hukum Islam Menurut AlQaradhawiy". el-Buhuth 1, no. 1 (2018). 